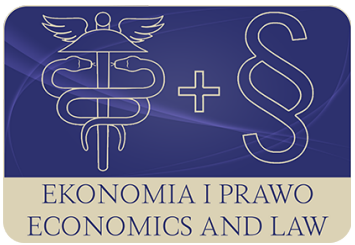

EKONOMIA I PRAWO. ECONOMICS AND LAW

Volume 19, Issue 4, December 2020

p-ISSN 1898-2255, e-ISSN 2392-1625

www.economicsandlaw.pl

EKONOMIA I PRAWO
ECONOMICS AND LAW

ORIGINAL ARTICLE

received 15.03.2020; revised 19.05.2020; accepted 31.12.2020

Citation: Szulc-Obłoza, A. (2020). Wage regulations and shadow economy in 28 European

Countries. Ekonomia i Prawo. Economics and Law, 19(4): 789-799. doi:10.12775/EiP.2020.051.

\title{
Wage regulations and shadow economy in 28 European Countries
}

\author{
AGNIESZKA SZULC-OBEOZA \\ Nicolaus Copernicus University in Toruń, Faculty of Economic Sciences and Management, \\ Department of Human Resource Management, ul. Gagarina 13a, 87-100 Toruń, Poland \\ 曰aszulc@umk.pl \\ orcid.org/0000-0002-7281-6813
}

\begin{abstract}
Motivation: The regulations are seen as the push factor into shadow sphere. The identification of determinants of shadow economy is crucial element mainly due to policy reasons. However, the analysis of the shadow economy is challenging mainly because of the identification problems. Actors from the shadow sphere hide this activity intently. Additionally determinants, consequences and size of phenomena are changing all the time and vary from country to country.

Aim: The main aim of the article is to analyse the relation of regulations on the labour market related to wages and shadow economy in 28 European countries in 2013 and 2016. Additionally, the author builds the ranking of countries to collate the selected regulations in European countries on the basis of created synthetic measure.

Results: The relation between regulations concerning wages and shadow economy on the low level was identified. The built ranking of countries in 2013 and 2016 was opened by Denmark and Sweden as least regulated countries in the group of 28 European states. Additionally, in 2013 Germany was classified to the group of not regulated elements included in synthetic measure.
\end{abstract}

Keywords: shadow economy; regulations; informal labour market JEL: E26; G38; J46 


\section{Introduction}

Shadow economy as well as undeclared work are the phenomenon interdependent with official economy and inseparably connected to each country (Jensen et al., 2009, p. 8).

Shadow economy is understood as all market-based legal production of goods and services that are concealed from public authorities. Undeclared work includes activities performed in the hidden economy and analysed through labour market perspective. In the article, shadow economy is defined as activities that are lawful in their nature but not declared to the public authorities to avoid: payments of taxes, social security contributions, labour market standards, administrative procedures (Buehn \& Schneider, 2009, p. 2; European Commission, 1998, p. 4; Williams, 2008, p. 364).

Real economic actions are far more complex than a simple categorization as formal or informal (Godfrey, 2011, p. 233). Official activities as well as shadow ones may be characterized as heterogeneous and intermingled. In practice, the possibility of distinction between formal and informal sphere is not easy. Williams (2008, p. 364) questions clear duality among formal and informal work and highlights intertwining of spheres. In first hypothetical situation, there is no official contract between parties and there is also an option that declared employees receive envelope wages additionally to the official, declared salaries. In the first case, the income from whole work is not declared to state authorities and in the second, only part of acquired income is announced. Regulations affecting level of wages play an interesting role. On one hand, sustain the barrier to work in formal economy but on the other, may encourage to disguise the part of activity, such as night work, weekly rest day or overtime.

According to the voluntary school, actors consider costs and benefits of informality versus to formality (Loayza, 1999, p. 4). Participants of informal sector compare the pros and cons and voluntarily take decisions about activity in informal sector. The voluntarist perspective highlights the role of regulations and taxation in pushing to informal sector (Chen, 2012, p. 5). Maloney (2004, p. 1173) admits, that benefits provision acquired from formal sector is frequently inefficient and of poor quality. That in consequence, increases the attractiveness of informal work.

\section{Literature review}

The willingness of avoiding legal labour regulations appears in the group of reasons of shadow economy (Alanon \& Gomez-Antonio, 2005, p. 1014; Buehn \& Schneider, 2009, p. 2; Dell'Anno \& Solomon, 2006, p. 2; Medina \& Schneider, 2019, p. 6; Portes, 2010, pp. 136-148; Zagorsek et al., 2009, p. 39). Excessive regulations push actors into shadow sphere (Betcherman, 2019, p. 5; Fleming et al., 2000, p. 394; Loayza, 1999, p. 2; Zoido-Lobaton et al., 1999). In this situation, we can observe that 'order creates disorder' (Lomnitz, 1988, pp. 42-43). 
Minimum wages, maximum working hours, duration of contract, union density, safety standards, paid vacations, sick leave and health insurance are included in the literature as labour market regulations which affect informal work (Buehn \& Schneider, 2009, p. 2; Eichhorst et al., 2008, p. 4; Loayza, 1999, p. 6). Aspects connected to taxes as taxes laid on labour, tax complexity or tax morale are also analysed in the literature as determinants of shadow activities (Estrin \& Mickiewicz, 2012, p. 564; Fleming et al., 2000, pp. 394-395).

In the theoretical model considering the allocation of labour between official and unofficial sectors of the economy built by Johnson et al. (1997, pp. 185-190) include regulations as determinants of shadow economy. Authors confirmed the negative relation between regulations and unofficial economy by theoretical model which additionally found support with data set. In publication revised in 1999, the association of overregulation with more unofficial activity across countries was confirmed (Friedman et al., 2000, pp. 459-493). However, authors highlight the negative role of overregulation, not regulation itself. Therefore, question arises about the desirable level of regulations.

Loayza (1994, p. 2) argues that regulations in theory are designed to improve workers situation. They should balance the need to protect rights of workers and creation of productive employment opportunities (Kuddo, 2018, p. 6). According to Botero et al. (2004, p. 1343) prevention of discrimination in the labour market and endowment workers with the basic rights are first of four forms of protecting workers through regulations. The example of this form is minimum wage. Regulations of employment relationships such as restriction of hours of work are the second form. Empowerment of labour union and social insurance are the remaining forms of regulations. The protection of workers by government intervention is effective only when severe consequences are not observed. The growth of unofficial economy as consequence is highlighted.

In practise, actors who perform work in informal sector perceive the benefits of doing so to outweigh the costs of going formal (Djankov et al., 2003, p. $63,65-72$ ). What is essential, the choice of informal sector is the activity that breaks the rules. In other words, this behaviour should not be promoted as desirable (Williams \& Windebank, 1998, p. 152).

\section{Methods}

The taxonomy analysis was performed. Wage regulations as rules affecting the wage level were treated as a multi-dimensional space which is characterized by set of the potential diagnostic variables. In the paper, the effect of labour market regulations affecting wages, namely: monthly minimum wage, premium for night work, premium for work on weekly rest day, premium for overtime work, standard workday and maximum working days per week are considered. The set of potential diagnostic variables were chosen on the basis of merits and formal criteria concerning regulations. To the group of regulations affecting the level of wages would also be included taxes, but they are involved to the estimation 
of shadow economy (Kelmanson et al., 2019, p. 16; Medina \& Schneider, 2019, p. 10; Schneider, 2016, p. 7). That fact excludes the taxes sphere from analysis of relation between regulations and shadow economy. The data were obtained from Eurostat (2020) and Doing Business (2020) database. 28 European Union countries as objects were selected. The analysis is done mainly for 2016 but in order to have a possibility of comparing the levels of the synthetic measure 2013 is included. Despite the fact that on 1 February 2020 the United Kingdom is no longer part of the European Union to the analysis was included because in chosen years it was the part of community.

In next step, the diagnostic set of variables was analysed in order to keep low level of similarity and low correlation among set of data conditions (variability coefficient which exceed the threshold value of $10 \%$, the Pearson correlation coefficient not more than 0.8) (Malina, 2000, p. 127; Zeliaś, 2000, p. 37). Standard workday and maximum working days per week were excluded from the diagnostic group because variability coefficient does not exceed the threshold value of $10 \%$ (4.2\% and 5.9\% respectively in 2013 and 2016).

After specification of final diagnostic variables, the normalization process was applied (Kukuła, 2000, pp. 224-227). The following formula of zero unitarization method to all variables which were stimulants was used:

$$
z_{i j}=\frac{y_{i j}-\min _{i}\left\{y_{i j}\right\}}{\max _{i}\left\{y_{i j}\right\}-\min _{i}\{y i j\}},
$$

where $y_{i j}$ is the value of analysed $j$-variable $(j=1,2,3,4)$ in $i$-country $(i=1,2, \ldots$, 28).

In the next step, the synthetic measure was achieved by calculation of mean of final set of diagnostic variables for each country (i-object) (Malina \& Wanat, 2000, pp. 134-135). For selected years countries were ordered by synthetic measure of regulations from smallest to largest.

Additionally, to measure the dependence between the synthetic measure of regulations and informal employment the Pearson's correlation coefficient was applied. Assumed the p-value (significance level) of the correlation on the $10 \%$ level. Because of the challenge of observation, the sphere which is intentionally hidden, different estimations of shadow economy were used (table 1). First estimation performed by Schneider (2016), second one by Medina \& Schneider (2019) and third one by Kelmanson et al. (2019).

\section{Results}

The ranking of countries ordered by the freest from wage regulations to the strictly regulated in 2016 was opened by Denmark and Sweden (table 2). Denmark and Sweden were located at first two positions also in 2015 and 2017. These countries did not regulate analysed spheres in synthetic measure. Moreover, in 2013 to the group of not regulated analysed spheres belonged Germany. 
In 2016 Denmark, Sweden and additionally Belgium, Italy, Spain, Croatia and Germany were classified to the group of countries for which, more than $75 \%$ of countries noted higher value of synthetic measure. This group may be characterized as relatively not regulated. However, Slovenia, Malta, Austria, Latvia, Poland, Romania and Lithuania noted the highest synthetic measure in 2016 , it is more than $75 \%$ of countries noted lower value of measure. Value around median was identified in France and Bulgaria in 2016. In 2016 as well as in 2013 Lithuania ended the ranking with most regulated areas included into synthetic measure (table 2).

The most spectacular changes in ranking within 2013 and 2016 were observed in: Hungary ( +6 positions) and Germany ( -5 positions). Hungary noticed a huge change, moved from the one before last place to 21st in 2016, it means that in the components of synthetic measure, weakening of regulations were observed (table 2). According to Act CII of 2014 on amendments to the Labour Code the rules of working on Sundays were changed and came into force in 2015 what took effect in promotion (LABREF, 2020). Germany from second position to the seventh one moved within three years, it means that range of regulations were wider in 2016. The drop in the ranking was the effect of introduction of statutory minimum wage as one of the most significant institutional change in Germany after 'Hartz' reforms in 2003-2005 (Bonin et al., 2020, p. 1).

The results of the correlation between synthetic measure of regulations and shadow economy pointed that more regulated analysed spheres, the wider range of shadow economy (table 3). In other words, more regulations mean more identified benefits of informality. All relationships were significant on the presupposed value $(\mathrm{p}=10 \%)$. Weak positive levels of correlation were observed in 2013 and 2016 - factors range between 0.3-0.4. In other words, only the slight difference in relation between regulations and different methods of calculated shadow economy was noticed. In case of calculation of shadow economy made by Kelmanson et al. (2019), the relationship amounted to 0.3349 in 2013 and 0.3474 in 2016. In case of estimations performed by Medina \& Schneider (2019), connection between two areas was quantified on 0.3609 in 2013 and 0.3387 in 2016. However, taking into consideration calculation of Schneider (2016), the relationship between synthetic measure and shadow economy was higher but still on the low level, because amounted to 0.4157 and 0.4425 respectively (table 3 ).

\section{Conclusion}

The question about the way to reduce the attractiveness of the shadow economy is still actual mainly because of the policy reasons. The positive relation between wage regulations and shadow economy was identified. What is interesting, that even the change of one regulation affects the overall picture and in consequence change the position of the country in the built ranking. The change of one ele- 
ment affects also pros and cons of activity in the informal sector. What in fact influence the level of shadow economy.

The main challenge for policymakers is to find the level of regulations which preserve workers and do not push into shadow sphere at the same time. Other factors creating the circumstances in which actors take decisions also play an important role. To the group of other regulations not included into synthetic measure active and passive labour market programmes, social security payments would be mentioned (Eichhorst et al., 2008, pp. 4-5; Pilc, 2015, pp. 99100; Ruge, 2010, pp. 515-520). The examples of factors influencing the level of shadow economy, but not directly connected to the labour market are social structures, level of development, trust in public authorities, acceptance of risk, extent of control rights, corruption and public acceptance of informality (Carter 1984, pp. 211-212; Estrin \& Mickiewicz, 2012, p. 564; Oviedo et al., 2009, p. 20). All these elements create environment in which actors evaluate benefits and costs of activities in official and shadow sphere but are difficult to include in the analysis because of the availability of data.

\section{References}

Alanon, A., \& Gomez-Antonio, M. (2005). Estimating the size of the shadow economy in Spain: a structural model with latent variables. Applied Economics, 37(9). doi:10.1080/00036840500081788.

Betcherman, G. (2019). Designing labor market regulations in developing countries. IZA World of Labor, 57(2). doi:10.15185/izawol.57.v2.

Bonin, H., Isphording, I. E., Krause-Pilatus, A., Lichter, A., Pestel, N., \& Rinne, U. (2020). The German statutory minimum wage and its effects on regional employment and unemployment. Jahrbücher Für Nationalökonomie Und Statistik, 240(2-3). doi:10.1515/jbnst-2018-0067.

Botero, J.C., Djankov, S., La Porta, R., Lopez-de-Silanes, F., \& Shleifer, A. (2004). The regulation of labor. The Quartely Journal of Economics, 119(4). doi:10.1162/0033553042476215.

Buehn, A., \& Schneider, F. (2009). Shadow economies and corruption all over the world: revised estimates for 120 countries. Economics: The Open-Access, Open-Assessment E-Journal, 1. doi:10.5018/economics-ejournal.ja.2007-9.

Carter, M. (1984). Issues in the hidden economy: a survey. The Economic Record, 60(3). doi:10.1111/j.1475-4932.1984.tb00856.x.

Chen, M.A. (2012). The informal economy: definitions, theories and policies. WIEGO Working Paper, 1.

Dell'Anno, R., \& Solomon, O.H. (2006). Shadow economy and unemployment rate in USA: is there a structural relationship: an empirical analysis. Applied Economics, 40(19). doi:10.1080/00036840600970195. 
Djankov, S., Lieberman, I., Mukherjee, J., \& Nenova, T. (2003). Going informal: benefits and costs. In B. Belev (Ed.), The informal economy in the EU accession countries: size, scope, trends and challenges to the process of EU enlargement. Sofia: Center for Study of Democracy.

Doing Business. (2020). Retrieved 01.02.2020 from https://www.doingbusiness.org.

Eichhorst, W., Feil, M., \& Braun, C. (2008). What have we learned: assessing labor market institutions and indicators. IZA Discussion Paper, 3470.

Estrin, S., \& Mickiewicz, T. (2012), Shadow economy and entrepreneurial entry. Review of Development Economics, 16(4). doi:10.1111/rode.12004.

European Commission. (1998). Communication of the Commission on undeclared work (COM (98) 219).

Eurostat. (2020). Retrieved 01.02.2020 from https://ec.europa.eu.

Fleming, M.H., Roman, J., \& Farrell, G. (2000). The shadow economy. Journal of International Affairs, 53(2).

Friedman, E., Johnson, S., Kaufmann, D., \& Zoido-Lobaton, P. (2000). Dodging the grabbing hand: the determinants of unofficial activity in 69 countries. Journal of Public Economics, 76(3). doi:10.1016/s0047-2727(99)00093-6.

Godfrey, P.C. (2011). Toward a theory of the informal economy. The Academy of Management Annals, 5(1). doi:10.1080/19416520.2011.585818.

Jensen, P.H., Pfau-Effinger, B., \& Flaquer, L. (2009). The development of informal work in the work-welfare arrangements of European societies. In B. Pfau-Effinger, L. Flaquer, P.H. Jensen (Eds.), Formal and informal work: the hidden work regime in Europe. New York: Routledge.

Johnson, S., Kaufmann, D., Shleifer, A., Goldman, M.I., \& Weitzman, M.L. (1997). The unofficial economy in transition. Brooking Papers on Economic Activity, 2. doi:10.2307/2534688.

Kelmanson, B., Kirabaeva, K., Medina, L., Mircheva, B., \& Weiss, J. (2019). Explaining the shadow economy in Europe: size, causes and policy options. IMF Working Paper, 278. doi:10.5089/9781513520698.001.

Kuddo, A. (2018). Labor regulations throughout the world: an overview. doi:10.1596/30106.

Kukuła, K. (2000). Metoda unitaryzacji zerowanej. Warszawa: PWN.

LABREF. (2020). Retrieved 01.02.20200 from https://webgate.ec.europa.eu.

Loayza, N.V. (1994). Labor regulations and the informal economy. Policy Research Working Paper, 1335.

Loayza, N.V. (1999). The economics of the informal sector: a simple model and some empirical evidence from Latin America. Policy Research Working Papers. doi:10.1596/1813-9450-1727.

Lomnitz, L.A., (1988). Informalexchangenetworksinformalsystems: atheoretical model. American Anthropologist, 90(1). doi:10.1525/aa.1988.90.1.02a00030.

Malina, A. (2000). Określenie zbioru finalnych zmiennych diagnostycznych. In A. Zeliaś (Ed.), Taksonomiczna analiza przestrzennego zróżnicowania poziomu życia w Polsce w ujęciu dynamicznym. Kraków: AE w Krakowie. 
Malina, A., \& Wanat, S. (2000). Wyznaczenie syntetycznego miernika poziomu życia ludności. In A. Zeliaś (Ed.), Taksonomiczna analiza przestrzennego zróżnicowania poziomu życia $w$ Polsce $w$ ujęciu dynamicznym. Kraków: AE w Krakowie.

Maloney, W.F. (2004). Informality revisited. World Development, 32(7). doi:10.1016/j.worlddev.2004.01.008.

Medina, L., \& Schneider, F. (2019). Shedding light on the shadow economy: a global database and the interaction with the official one. Cesifo Working Paper, 7981.

Oviedo, A.M., Thomas, M.R., \& Karakurum-Ozdemir, K. (2009). Economic informality, causes, costs, and policies: a literature survey. World Bank Working Paper, 167. doi:10.1596/978-0-8213-7996-7.

Pilc, M. (2015). Determinants of the labour market institutions in post-socialist economies. Communist and Post-Communist Studies, 48(2-3). doi:10.1016/j. postcomstud.2015.06.008.

Portes, A. (2010). Economic sociology: a systematic inquiry. Princeton: Princeton University Press.

Ruge, M. (2010). Determinants and size of the shadow economy: a structural equation model. International Economic Journal, 24(4). doi:10.1080/10168737 .2010 .525988 .

Schneider, F. (2016). Trotz gegenläufiger Tendenzen (Anstieg der Arbeitslosigkeit und fer Flüchtlinge) ein Rückgang der Schattenwirtschaft (des Pfusch) in Österreich in 2016. Retrieved 20.02.2020 from https://www.jku.at.

Williams, C., \& Windebank, J. (1998). Informal employment in the advanced economies: implications for work and welfare. New York: Routledge.

Williams, C.C. (2008). Envelope wages in Central and Eastern Europe and the EU. Post-Communist Economies, 20(3). doi:10.1080/14631370802281472.

Zagorsek, H., Jaklic, M., \& Hribernik, A. (2009). The shadow economy and its impact on national competitiveness: the case of Slovenia. South East European Journal of Economics and Business, 4(1). doi:10.2478/V10033-009-0003-6.

Zeliaś, A. (2000). Kryteria doboru zmiennych diagnostycznych. In A. Zeliaś (Ed.), Taksonomiczna analiza przestrzennego zróżnicowania poziomu życia $w$ Polsce w ujęciu dynamicznym. Kraków: AE w Krakowie.

Zoido-Lobaton, P., Johnson, S., \& Kaufmann, D. (1999). Corruption, public finances, and the unofficial economy. Policy Research Working Papers. doi:10.1596/1813-9450-2169.

\section{Acknowledgements}

Author contributions: author has given an approval to the final version of the article.

Funding: this research was funded by the Nicolaus Copernicus University in Torun, Faculty of Economic Sciences and Management statutory sources. 


\section{Appendix}

Table 1.

Shadow economy in 28 European countries in 2013 and 2016

\begin{tabular}{|c|c|c|c|c|c|c|}
\hline \multirow[b]{2}{*}{ Country } & \multicolumn{3}{|c|}{2013} & \multicolumn{3}{|c|}{2016} \\
\hline & $\begin{array}{c}\text { Shadow } \\
\text { economy } \\
\text { (Kelmanson } \\
\text { et al., 2019) }\end{array}$ & $\begin{array}{l}\text { Shadow economy } \\
\text { (Medina \& } \\
\text { Schneider, 2019) }\end{array}$ & $\begin{array}{c}\text { Shadow } \\
\text { economy } \\
\text { (Schneider, } \\
\text { 2016) }\end{array}$ & $\begin{array}{l}\text { Shadow } \\
\text { economy } \\
\text { (Kelmanson } \\
\text { et al., 2019) }\end{array}$ & $\begin{array}{l}\text { Shadow economy } \\
\text { (Medina \& } \\
\text { Schneider, 2019) }\end{array}$ & $\begin{array}{c}\text { Shadow } \\
\text { economy } \\
\text { (Schneider, } \\
\text { 2016) }\end{array}$ \\
\hline Austria & 9.40 & 7.00 & 7.50 & 9.60 & 7.40 & 7.80 \\
\hline Belgium & 21.80 & 16.60 & 16.40 & 22.10 & 16.90 & 16.10 \\
\hline Bulgaria & 38.10 & 24.80 & 31.20 & 37.80 & 24.00 & 30.20 \\
\hline Croatia & 36.70 & 24.00 & 28.40 & 35.00 & 23.60 & 27.10 \\
\hline Cyprus & 32.00 & 27.00 & 25.20 & 30.40 & 26.70 & 24.20 \\
\hline Czech Republic & 18.00 & 12.70 & 15.50 & 19.40 & 12.30 & 14.90 \\
\hline Denmark & 18.40 & 11.90 & 13.00 & 18.40 & 12.10 & 11.60 \\
\hline Estonia & 33.40 & 19.60 & 27.60 & 34.60 & 20.90 & 25.40 \\
\hline Finland & 19.30 & 11.10 & 13.00 & 20.00 & 11.40 & 12.00 \\
\hline France & 14.90 & 11.60 & 9.90 & 15.00 & 12.20 & 12.60 \\
\hline Germany & 15.30 & 9.90 & 12.10 & 16.70 & 10.70 & 10.80 \\
\hline Greece & 30.40 & 23.70 & 23.60 & 30.20 & 25.40 & 22.00 \\
\hline Hungary & 26.00 & 19.90 & 22.10 & 26.90 & 20.50 & 22.20 \\
\hline Ireland & 16.00 & 11.70 & 12.20 & 15.80 & 9.70 & 10.80 \\
\hline Italy & 26.90 & 20.00 & 21.10 & 27.30 & 20.60 & 20.20 \\
\hline Latvia & 29.70 & 18.40 & 25.50 & 29.60 & 18.80 & 22.90 \\
\hline Lithuania & 35.00 & 20.50 & 28.00 & 35.30 & 21.00 & 24.90 \\
\hline Luxembourg & 9.70 & 8.70 & 8.00 & 9.70 & 8.70 & 8.40 \\
\hline Malta & $22.60^{*}$ & 22.60 & 24.30 & $20.10^{*}$ & 20.10 & 24.00 \\
\hline Netherlands & 13.50 & 9.00 & 9.10 & 13.30 & 9.10 & 8.80 \\
\hline Poland & 26.70 & 19.90 & 23.80 & 27.80 & 20.40 & 23.00 \\
\hline Portugal & 24.60 & 17.50 & 19.00 & 24.50 & 17.10 & 17.20 \\
\hline Romania & 34.90 & 23.70 & 28.40 & 34.80 & 23.80 & 27.60 \\
\hline Slovak Republic & 19.00 & 12.90 & 15.00 & 19.50 & 13.20 & 13.70 \\
\hline Slovenia & 29.10 & 20.80 & 23.10 & 28.00 & 20.20 & 23.10 \\
\hline Spain & 20.50 & 21.10 & 18.60 & 20.30 & 21.30 & 17.90 \\
\hline Sweden & 19.60 & 10.20 & 13.90 & 18.80 & 10.90 & 12.60 \\
\hline United Kingdom & 12.60 & 9.50 & 9.70 & 12.90 & 9.70 & 9.00 \\
\hline
\end{tabular}

Notes:

* Because of missing value the level acquired from Schneider (2016) research.

Source: Kelmanson et al. (2019, pp. 25-26), Medina \& Schneider (2019, pp. 38-49), Schneider (2016, p. 5, 8). 
Table 2.

Ranking of 28 European countries in 2013 and 2016

\begin{tabular}{|c|c|c|c|c|c|}
\hline $\begin{array}{c}\text { No. } \\
\text { in } 2013\end{array}$ & Country & $\begin{array}{c}\text { Synthetic measure } \\
\text { in } 2013\end{array}$ & $\begin{array}{c}\text { No. } \\
\text { in } 2016\end{array}$ & Country & $\begin{array}{c}\text { Synthetic measure } \\
\text { in } 2016\end{array}$ \\
\hline 1 & Denmark & 0.0000 & 1 & Denmark & 0.0000 \\
\hline 2 & Germany & 0.0000 & 2 & Sweden & 0.0000 \\
\hline 3 & Sweden & 0.0000 & 3 & Belgium & 0.1250 \\
\hline 4 & Belgium & 0.1250 & 4 & Italy & 0.1685 \\
\hline 5 & Spain & 0.1668 & 5 & Spain & 0.1941 \\
\hline 6 & Italy & 0.1685 & 6 & Croatia & 0.1998 \\
\hline 7 & Croatia & 0.1770 & 7 & Germany & 0.2028 \\
\hline 8 & United Kingdom & 0.1911 & 8 & Netherlands & 0.2137 \\
\hline 9 & Ireland & 0.2067 & 9 & United Kingdom & 0.2187 \\
\hline 10 & Netherlands & 0.2111 & 10 & Ireland & 0.2207 \\
\hline 11 & Slovak Republic & 0.2420 & 11 & Czech Republic & 0.3013 \\
\hline 12 & Czech Republic & 0.2834 & 12 & Slovak Republic & 0.3290 \\
\hline 13 & Greece & 0.3495 & 13 & Greece & 0.3495 \\
\hline 14 & Bulgaria & 0.3520 & 14 & France & 0.3696 \\
\hline 15 & France & 0.3735 & 15 & Bulgaria & 0.3764 \\
\hline 16 & Estonia & 0.3866 & 16 & Estonia & 0.4101 \\
\hline 17 & Finland & 0.4049 & 17 & Finland & 0.4310 \\
\hline 18 & Portugal & 0.4128 & 18 & Cyprus & 0.5000 \\
\hline 19 & Cyprus & 0.5000 & 19 & Luxembourg & 0.5056 \\
\hline 20 & Luxembourg & 0.5070 & 20 & Portugal & 0.5265 \\
\hline 21 & Slovenia & 0.5750 & 21 & Hungary & 0.5301 \\
\hline 22 & Poland & 0.5905 & 22 & Slovenia & 0.5725 \\
\hline 23 & Malta & 0.6002 & 23 & Malta & 0.6006 \\
\hline 24 & Romania & 0.6116 & 24 & Austria & 0.6250 \\
\hline 25 & Austria & 0.6250 & 25 & Latvia & 0.6652 \\
\hline 26 & Latvia & 0.6413 & 26 & Poland & 0.6792 \\
\hline 27 & Hungary & 0.6503 & 27 & Romania & 0.7415 \\
\hline 28 & Lithuania & 0.7916 & 28 & Lithuania & 0.8116 \\
\hline \multicolumn{2}{|c|}{ quartile 1} & 0.1876 & \multicolumn{2}{|c|}{ quartile 1} & 0.2110 \\
\hline \multicolumn{2}{|c|}{ quartile 2 (median) } & 0.3627 & \multicolumn{2}{|c|}{ quartile 2 (median) } & 0.3730 \\
\hline \multicolumn{2}{|c|}{ quartile 3} & 0.5789 & \multicolumn{2}{|c|}{ quartile 3} & 0.5407 \\
\hline \multicolumn{2}{|c|}{ quartile 4} & 0.7916 & \multicolumn{2}{|l|}{ quartile 4} & 0.8116 \\
\hline
\end{tabular}

Source: Own preparation based on Doing Business (2020), Eurostat (2020). 
Table 3.

The Pearson's correlation coefficient between synthetic measure of wage regulations and shadow economy in 2013 and 2016

\begin{tabular}{cccc}
\hline Year & $\begin{array}{c}\text { Shadow economy } \\
\text { (Kelmanson et al., 2019) }\end{array}$ & $\begin{array}{c}\text { Shadow economy } \\
\text { (Medina \& Schneider, 2019) }\end{array}$ & $\begin{array}{c}\text { Shadow economy } \\
\text { (Schneider, 2016) }\end{array}$ \\
\hline \multirow{2}{*}{2013} & $r=0.3349$ & $r=0.3609$ & $r=0.4157$ \\
& $(p=0.8150)$ & $(p=0.0592)$ & $(p=0.0278)$ \\
2016 & $r=0.3474$ & $r=0.3387$ & $r=0.4425$ \\
& $(p=0.0700)$ & $(p=0.0779)$ & $(p=0.0184)$ \\
\hline
\end{tabular}

Source: Own preparation based on Doing Business (2020), Eurostat (2020), Kelmanson et al. (2019, pp. 25-26), Medina \& Schneider (2019, pp. 38-49), Schneider (2016, p. 5, 8). 
